\title{
IMPLEMENTASI METODE THROUGH SEAM BLAST DALAM MENDUKUNG OPERASIONAL PENAMBANGAN BATUBARA DI PIT C1 BLOK 8 BMO 2 PT BERAU COAL
}

\author{
Saeful Aziz ${ }^{1)}$, Qodri Hadi Putra ${ }^{2)}$, Aldo Brilianto ${ }^{3)}$, Ida Wayan Supriharta ${ }^{4)}$, Rahmantha \\ Purba Anggana ${ }^{5)}$ \\ ${ }^{1)}$ Mine Engineer and Data Analyst Bmo 2 Blok 8, PT Berau Coal \\ ${ }^{2)}$ Blasting Engineer Bmo 2 Blok 8, PT Berau Coal \\ ${ }^{3)}$ Pit Geologist Bmo 2 Blok 8, PT Berau Coal \\ ${ }^{4)}$ Short Term Planner Bmo 2 Blok 8, PT Berau Coal \\ ${ }^{5)}$ Mine Superintendent Bmo 2 Blok 8, PT Berau Coal
}

\begin{abstract}
ABSTRAK
Tujuan penelitian ini adalah untuk mengetahui: (1) kelayakan metode through seam blast untuk diimplementasikan pada area interburden dan batubara tipis dengan multi-seam. (2) Pengaruh terhadap peningkatan produktivitas, percepatan sekuen penambangan, kualitas batubara, dan konservasi batubara tipis. Dalam penelitian ini penulis bersama team yang yang dibentuk (terdiri dari pihak PT. Berau Coal site BMO 2, PT. Pamapersada Site BRCB, dan PT. DNX Site BMO 2) melakukan perencanaan menggunakan siklus plan, do, check, action (PDCA) terkait metode through seam blast dimana plan didukung dengan pendekatan konsep specipic, measurable, achievable, realistic dan timely (SMART). Pengumpulan data dilakukan dengan melakukan empat kali trial through seam blast. Hasil penelitian menunjukan bahwa : 1) Metode Through Seam Blast memungkinkan diimplementasikan di Pit $\mathrm{C} 1$ Blok 8 BMO 2 PT Berau Coal. (2) Terjadi peningkatan produktivitas alat gali muat sebesar $35 \mathrm{bcm} / \mathrm{jam}$ pada kelas $\mathrm{PC}-1200$, mengurangi frekuensi blasting dari 2-3 kali menjadi 1 kali pada luasan area yang sama, adanya deviasi ash batubara tertambang (terhadap as batubara insitu) yang masih masuk dalam toleransi sebesar $2.75 \%$, mine recovery tetap terjadi $\geq 98 \%$.
\end{abstract}

Kata kunci: through seam blast, produktivitas alat gali muat, frekuensi blasting, kualitas batubara, mine recovery

\begin{abstract}
The purpose of this study is to determine: (1) the feasibility of the through seam blast method to be implemented in inter burden areas and thin coal with multi-seam. (2) Effects on increasing productivity, acceleration of mining sequences, coal quality, and conservation of thin coal. In this study the authors together with the team formed (consisting of PT. Berau Coal site BMO 2, PT. Pamapersada Site BRCB, and PT. DNX Site BMO 2) do the planning using the related cycle plan, do, check, action (PDCA) a through seam blast method where the plan is supported by a specific, measurable, achievable, realistic and timely (SMART) concept approach. Data collection was carried out by conducting four trial through seam blasts. The results showed that: 1) Through Seam Blast method is possible to be implemented in Pit C1 Block 8 BMO 2 PT Berau Coal. (2) An increase in the productivity of the loading and unloading tool by $35 \mathrm{bcm} /$ hour in PC-1200 class, reducing the frequency of blasting from 2-3 times to 1 time in the same area, the deviation of mined coal ash (against the coal as in situ) still within tolerance of $2.75 \%$, mine recovery still occurs $\geq 98 \%$.
\end{abstract}

Keywords: through seam blast, digger productivity, blasting frequency, coal quality, mine recovery 


\section{A. PENDAHULUAN}

\section{A.1. Latar Belakang}

PT. Berau Coal merupakan tambang batubara yang terletak di Tanjung Redeb, Kalimantan Timur. PT. Berau Coal memiliki 3 daerah operasi tambang, yaitu Lati Mine Operation, Sambarata Mine Operation dan Binungan Mine Operation. Dari ketiga daerah operasi tambang memiliki 1 formasi yang sama, yaitu Formasi Lati. Formasi Lati terdapat di cekungan tarakan dengan perselingan batupasir, batu lempung, sisipan konglomerat, dan batubara. Formasi ini terendapkan pada lingkungan laut dangkal, dengan ketebalan 800 meter, dan berumur Miosen akhir-Pliosen. Metode penambangan yang diterapkan pada daerah operasi tambang adalah metode konvensional open pit.

Berdasarkan standar operasional prosedur PT Berau Coal Seam tipis didefinisikan sebagai seam dengan ketebalan $<50 \mathrm{~cm}$ (true thickness) mengacu pada spesifikasi unit loader coal getting yang menggunakan PC-300. Sementera Interburden didefinisikan berdasarkan spesifikasi unit loader dan hauler ob removal terbesar yaitu pada ketebalan <30 meter (horizontal thickness).

Berdasarkan data variasi ketebalan dan kemiringan interburden dan seam di Pit C1 Blok 8 BMO 2, terdapat beberapa interburden dan seam tipis pada area N, L dan J Group. Progress sekuen penambangan di area tersebut seringkali terlambat dikarenakan besarnya effort yang dikeluarkan mulai dari persiapan area pengeboran sampai tahapan penambangan batubara (gambar 1).

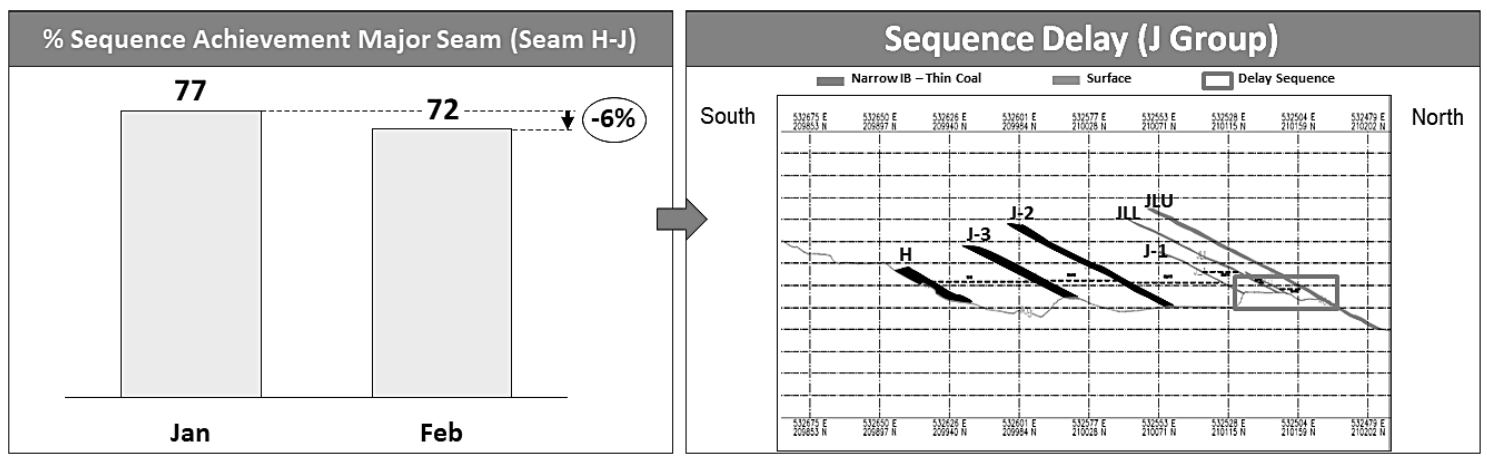

Gambar 1. Keterlambatan sekuen penambangan pada IB dan seam J group

Keterlambatan progress sekuen tidak hanya diakibatkan oleh tingginya lead time proses mulai dari preparasi lokasi sampai dengan loading batubara di area interburden dan seam tipis, tetapi juga dari rendahnya produktivitas alat gali muat di area tersebut sebagai dampak dari masalah material keras non-blasting yang tidak terakomodasi oleh peledakan konvensional. Tabel 1 menunjukan performa tahun 2018 menunjukkan material keras non blasting menjadi top problem productivity di area penambangan Pit C1 BMO 2 Blok 8 BMO 2 PT Berau Coal. Material keras non blasting merupakan wedge/pilar sisi floor seam batubara yg tidak mendapatkan dampak dari distribusi energi peledakan.

Tabel 1. Top 3 masalah produktivitas alat gali-muat Januari - November 2018

\begin{tabular}{ccccccccccccc}
\hline Problem Productivity & Jan & Feb & Mar & Apr & Mei & Jun & Jul & Agu & Sept & Okt & Nov & Total \\
\hline Material Keras Non-Blast & 568 & 619 & 505 & 393 & 287 & 403 & 398 & 556 & 526 & 342 & 368 & 4965 \\
Front Sempit & 578 & 537 & 574 & 358 & 269 & 230 & 237 & 280 & 388 & 549 & 439 & 4539 \\
Abnormal cycle - refuelling & 375 & 232 & 225 & 234 & 327 & 237 & 402 & 471 & 490 & 414 & 226 & 3633 \\
\hline
\end{tabular}

*catatan: data tersaji dalam satuan frekuensi kemunculan masalah

\section{A.2. Geologi}

Pit $\mathrm{C} 1$ merupakan pit aktif di Blok 8 BMO 2. Pit $\mathrm{C} 1$ merupakan penggabungan dari 3 pit aktif yaitu Pit CH (Basal seam H), Pit CM (Basal seam M), dan Pit C1E (Basal seam E). Sebelah Barat berbatasan dengan OPD C3 dan IPD C1, sebelah timur berbatasan dengan topografi perbukitan 
original, sebelah utaranya saat ini berbatasan dengan OPD C1 dan OPD C2, sedangkan di selatan berbatasan dengan OPD C1S , perbukitan original dan WMP 32 BT. Morfologi original area Pit C1 adalah perbukitan bergelombang rendah - tinggi yang diselingi dengan ceruk/ gully serta dataran rendah (gambar 2).

Berdasarkan data bor geologi dan geoteknik yang dilakukan pada beberapa titik di $\mathrm{Pit} \mathrm{CH}$, material penyusun lereng sebagian besar berupa batuan lempung (mudstone) dan sebagian kecil berupa batu pasir (sandstone) dengan kemiringan litologi batuan $\pm 16^{\circ}$. Lapisan penyusun interlaminasi juga mengikuti perlapisan batuan. Sedangkan pada area ceruk terisi oleh material endapan rawa dengan ketebalan yang beragam.

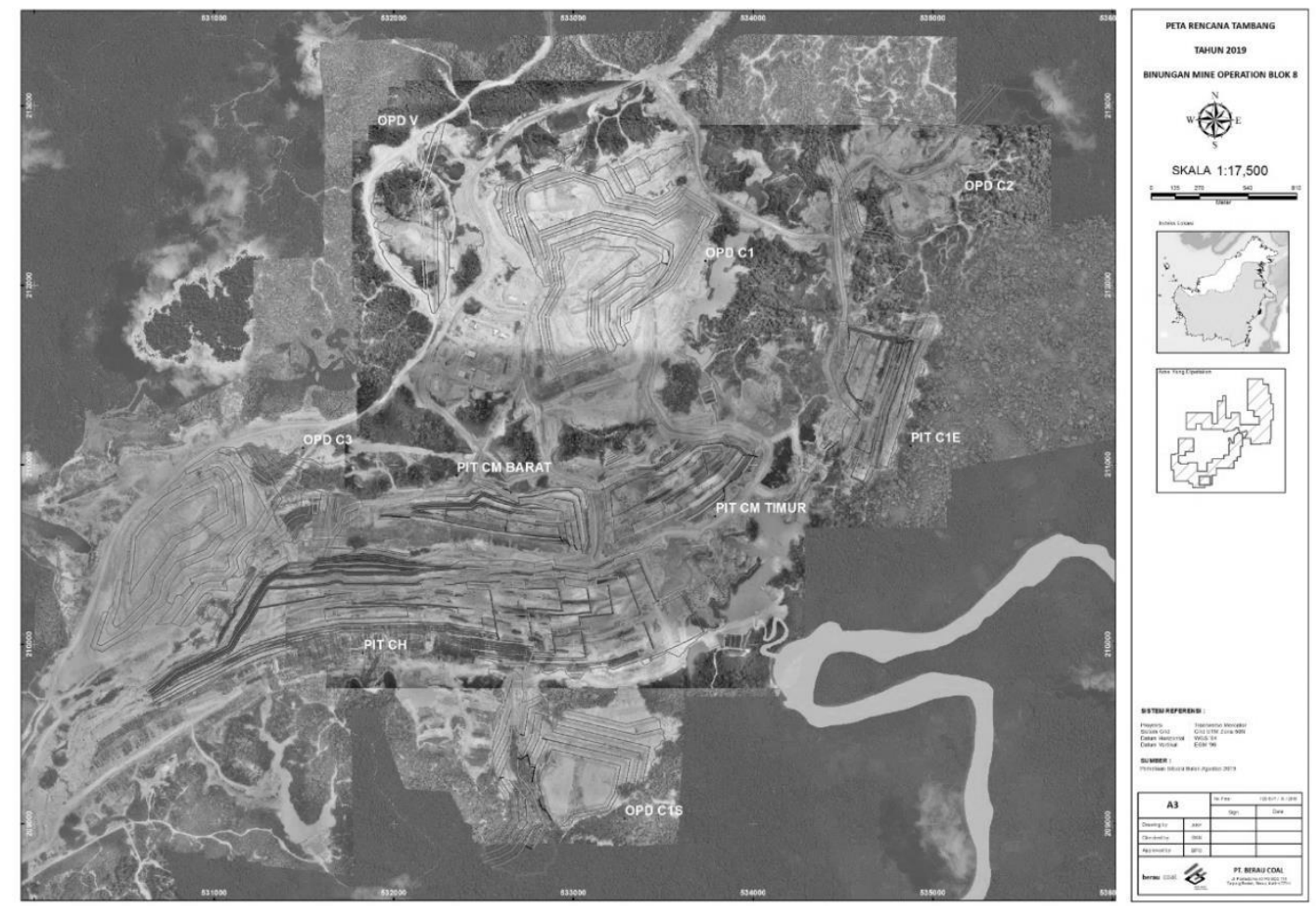

Gambar 2. Peta Rencana Tambang Pit C1 Blok 8 BMO 2 PT Berau Coal 2019

Stratigrafi daerah penelitian disusun berdasarkan pengelompokan litologi dominan yang dapat diamati di lapangan. Penamaan satuan batuan mengikuti tata nama satuan lithostatigrafi tidak resmi menurut Sandi Stratigrafi Indonesia (SSI, 1996). Berdasarkan hal tersebut di atas, maka daerah penelitian dapat dikelompokkan dalam 3 (tiga) satuan batuan tidak resmi, dengan urutan dari tua sampai muda, sebagai berikut:

1) Satuan Batupasir lempungan labanan

Satuan ini tersebar di bagian selatan daerah penelitian, menempati $\pm 40 \%$ dari luas keseluruhan daerah penelitian. Penamaan satuan ini didasarkan pada litologi batupasir dengan perselingan batulempung, batu lanau dan batubara. Struktur sedimen perlapisan laminasi sangat mendominasi pada satuan ini.

Mengacu pada stratigrafi regional menurut Situmorang dan Burhan (1995), berdasarkan kesamaan ciri fisik litologi penyusun satuan batuan, satuan ini termasuk dalam Formasi Labanan yang memiliki umur Miosen Akhir.

2) Satuan Batupasir konglomeratan labanan

Satuan ini tersebar di bagian utara daerah penelitian, menempati $\pm 50 \%$ dari luas keseluruhan daerah penelitian. Penamaan satuan ini didasarkan pada litologi batupasir 
dengan perselingan konglomerat, batupasir kerikilan dan batubara. Struktur sedimen cross bedding dan graded bedding sangat mendominasi pada satuan ini.

Mengacu pada stratigrafi regional menurut Situmorang dan Burhan (1995), berdasarkan kesamaan ciri lithologi dari satuan batupasir konglomeratan dengan ciri lithologi dari Formasi Labanan maka satuan ini berumur Miosen Akhir-Pliosen.

3) Satuan Endapan Alluvial

Satuan Endapan Alluvial tersebar di sebelah selatan dan timur daerah penelitian, mencakup $20 \%$ dari luas daerah penelitian. Endapan Alluvial merupakan endapan darat yang memiliki fragmen lepas berukuran berangkal hingga lempung serta material hasil erosi batuan yang lebih tua yang di kontrol oleh sungai yang memiliki stadia dewasa.

Endapan Alluvial ini berumur resen, mengacu kepada stratigrafi regional menurut Situmorang dan Burhan (1995) dan berkembang sampai sekarang, berada disepanjang tubuh sungai. Berdasarkan pengamatan di lapangan menunjukkan bahwa endapan ini bersifat lepas.

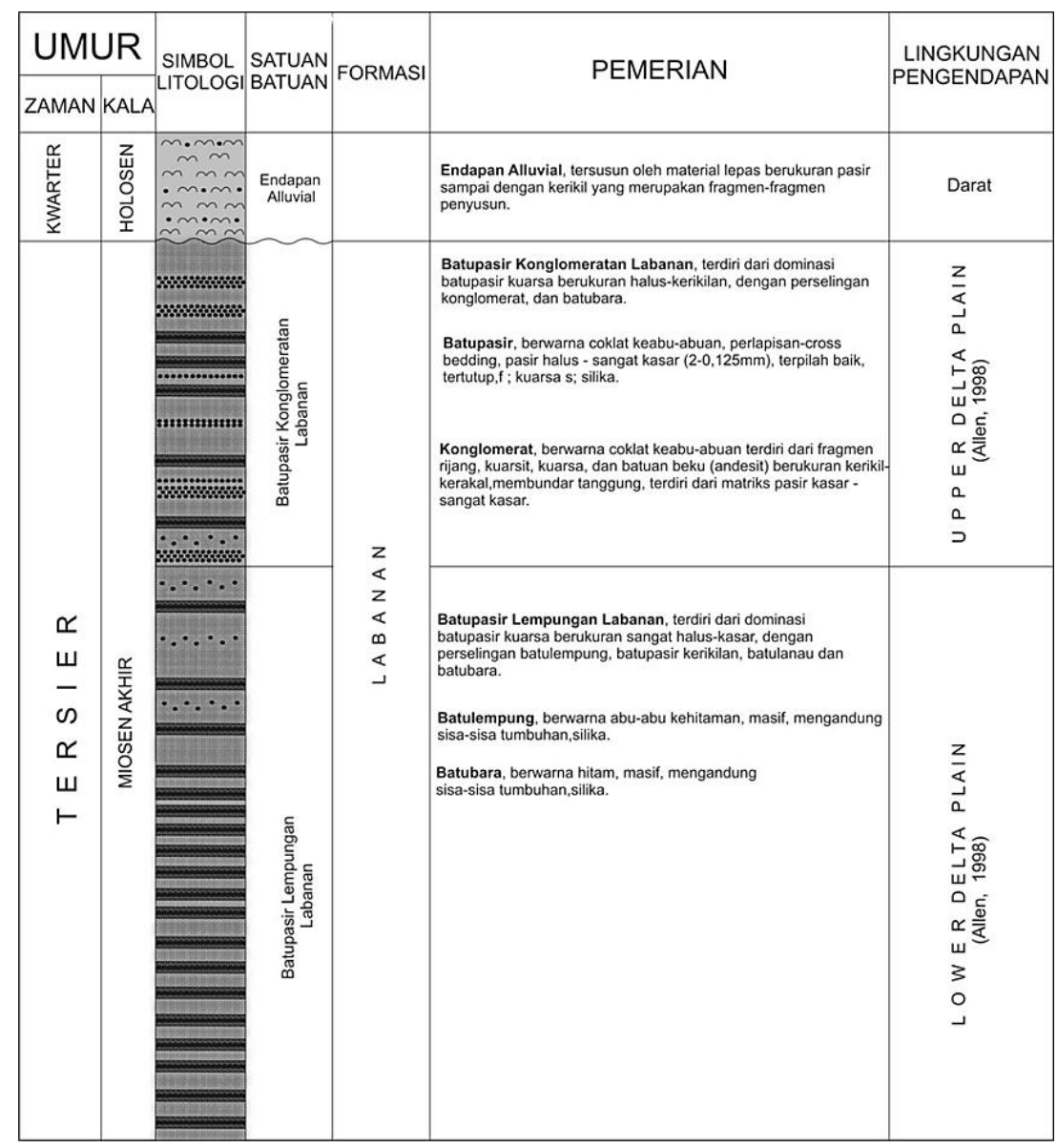

Gambar 3. Kolom Stratigrafi Daerah Penelitian (Aldo, 2010)

\section{A.3. Metodologi Peledakan}

Penentuan metode peledakan yang tepat menjadi salah satu kunci keberhasilan dalam proses penambangan. Metode peledakan eksisting yang diterapkan di Pit C1 Blok 8 BMO 2 PT Berau Coal adalah metode peledakan konvensional. Pada kondisi ideal, daya dukung metode peledakan konvensional cukup memadai dalam penyediaan material hasil peledakan yang optimal. Namun dalam kondisi tidak ideal seperti pada area dengan interburden dan seam tipis dan miring perlu 
dilakukan penanganan khusus yang terintegrasi dan komprehensif sehingga progress sekuen penambangan berjalan sesuai dengan rencana, produktif, efektif dan efisien.

Berdasarkan kajian awal yang dilakukan oleh team yang dibentuk khusus memecahkan permasalahan keterlambatan progress sekuen penambangan, metode through seam blast dianggap sebagai metode peledakan yang tepat untuk diimplementasikan di area interburden dan seam tipis dan miring. Metode through seam blast merupakan bagian dari metode peledakan dimana memungkinkan lubang ledak menembus satu atau lebih lapisan batubara dalam satu kali peledakan.

Dalam penelitian ini penulis bersama team yang yang dibentuk (terdiri dari pihak PT. Berau Coal site BMO 2, PT. Pamapersada Site BRCB, dan PT. DNX Site BMO 2) melakukan perencanaan menggunakan siklus plan, do, check, action (PDCA) terkait metode through seam blast dimana plan didukung dengan pendekatan konsep specipic, measurable, achievable, realistic dan timely (SMART). Pengumpulan data dilakukan dengan melakukan empat kali trial through seam blast.

\section{A.4. Tujuan}

Tujuan dari implementasi metode through seam blast di Pit C1 Blok 8 BMO 2 PT Berau Coal adalah untuk meningkatkan efisiensi penambangan di area interburden dan seam tipis dan miring mencakup parameter:

- Lead time persiapan area pengeboran sampai peledakan;

- Produktivitas alat gali muat;

- Kualitas dan kuantitas batubara.

\section{B. METODOLOGI PENELITIAN}

Pada penelitian ini penulis melakukan pendekatan metode tindakan dan metode trial and error. Kombinasi metode ini dipilih dilatar belakangi oleh implementasi metode through seam blast yang merupakan metode yang relatif baru dan belum pernah diimplementasikan di Pit $\mathrm{C} 1$ Blok 8 Binungan Mine Operation Area 2.

Kombinasi metodologi ini dianggap tepat oleh penulis dikarenakan penelitian dilakukan terhadap implementasi metode baru sehingga pada pelaksanaannya dilakukan pengujian berulang yang didasarkan pada kajian awal yang disempurnakan dengan data yang diperoleh pasca trial. Penulis berharap kombinasi metodologi ini dapat mendukung secara komprehensif tercapainya tujuan penelitian sehingga metode through seam blast ini dapat memberikan impact positif terhadap performa produksi dan dapat diimplementasikan secara berkelanjutan.

\section{HASIL DAN PEMBAHASAN}

\section{C.1. Metode Through Seam Blast}

Metode Through Seam Blast adalah sebuah metode peledakan yang bertujuan untuk mendapatkan beberapa hasil peledakan dalam satu proses tunggal. Satu proses peledakan tunggal yang di dalamnya meliputi Overburden, batubara, dan interburden.

Gambar 3 menunjukan ilustrasi proses through seam blast dan blasting konvensional pada area dip-multi-seam. Eksplisit informasi yang bisa didapatkan dari gambar 4 adalah terkait penuranan frekuensi blasting dan peningkatan kapasitas dan coverage volume blasting di suatu area. Turunanya berdampak terhadap percepatan progress sekuen penambangan, pengingkatan produktivitas alat gali-maut, penurunan delay blasting, dan konservasi batubara lebih optimal. 


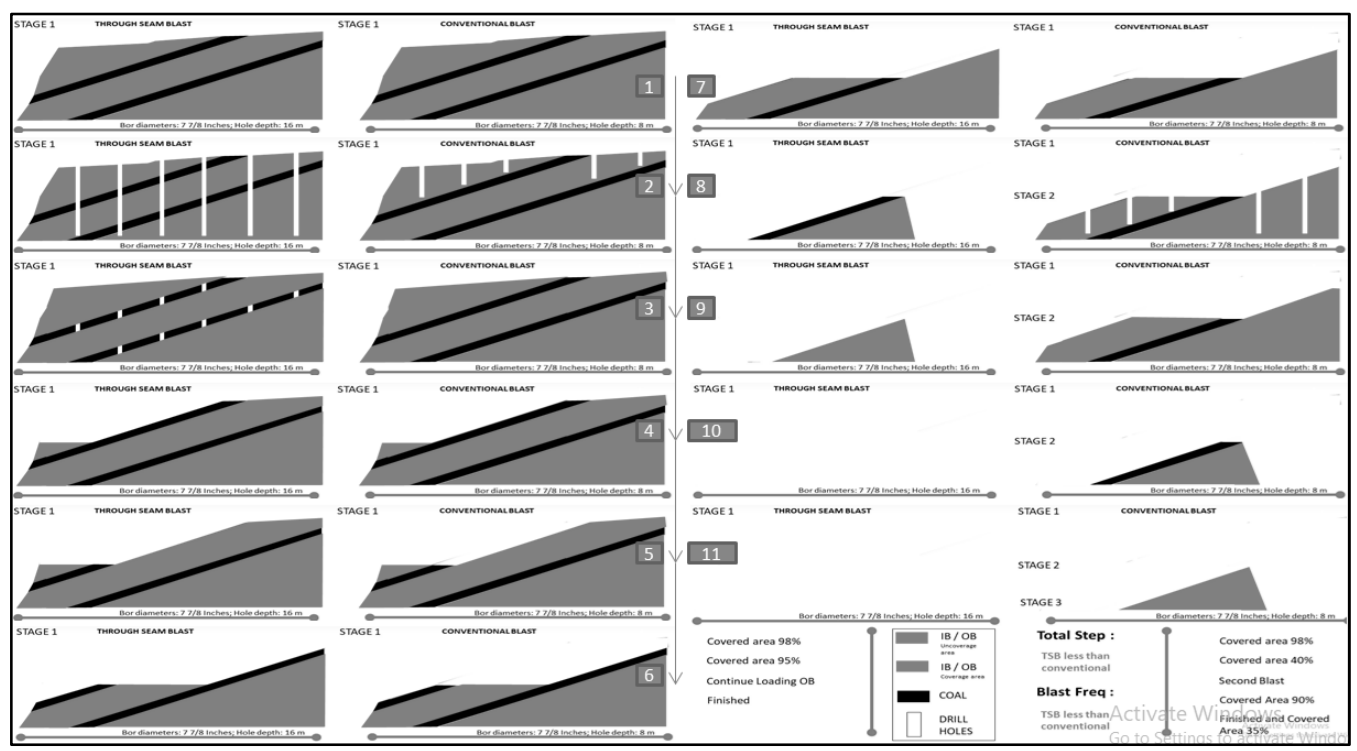

Gambar 4. Perbandingan Proses Through Seam Blast dan Blasting Konvensional

Berdasarkan kajian dengan mengacu pada landasan teoritis dan empiris, dalam proses trial implementasi metode through seam blast disepakati tiga parameter teknis peledakan yang akan menjadi fokus yaitu berkaitan dengan:

1. Fragmentasi

Untuk dapat menghasilkan fragmentasi yang optimal sehingga memberika dampak positif terhadap performa produktivitas alat gali muat, maka fokus team TSB adalah pada penggunaan powder factor yang sesuai dengan goemetri dan karakteristik batuan.

2. Interval batubara

Untuk dapat mendapatkan hasil interpretasi interval batubara secara akurat dan presisi, maka fokus team TSB adalah pada kontrol charging sheet dan gamma logging.

3. Vibrasi

Dengan bertambahnya kapasitas volume material akan diledakan pada area yang sama, metode through seam blast berpotensi menghasilkan getaran yang lebih besar dibandingkan dengan metode peledakan konvensional. Maka fokus team TSB adalah pada kontrol delay dan penggunaan elektronik detonator.

Harapannya kontrol terhadap tiga parameter teknis peledakan diatas dapat memberikan hasil peledakan yang optimal (Gambar 5).

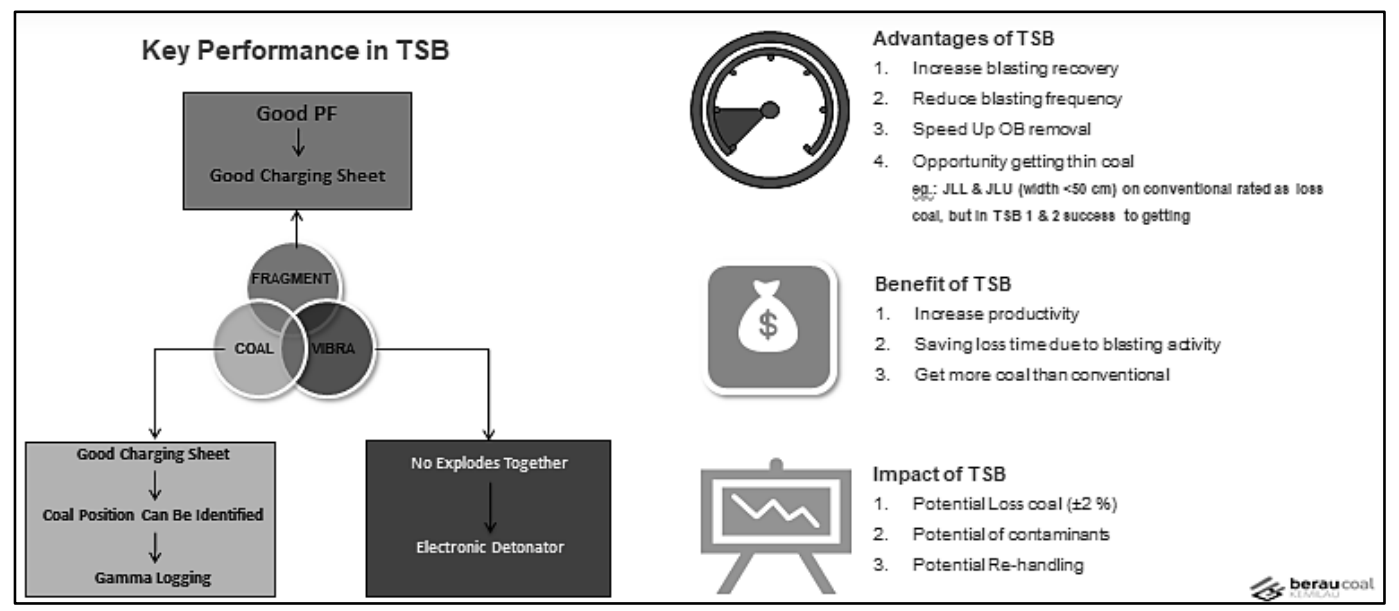

Gambar 5. Kunci keberhasilan TSB 
Gambar 6 menunjukan tahapan proses mulai dari persiapan lokasi yang akan diimplementasikan metode through seam blast di Pit C1 Blok 8 BMO 2 PT Berau Coal sampai dengan loading material overburden/interburden dan batubara. Pada pelaksanaannya, tahapan yang menjadi fokus penelitian tidak hanya sampai firing, tetapi sampai pada kuantitas dan kualitas batubara yang terangkut.

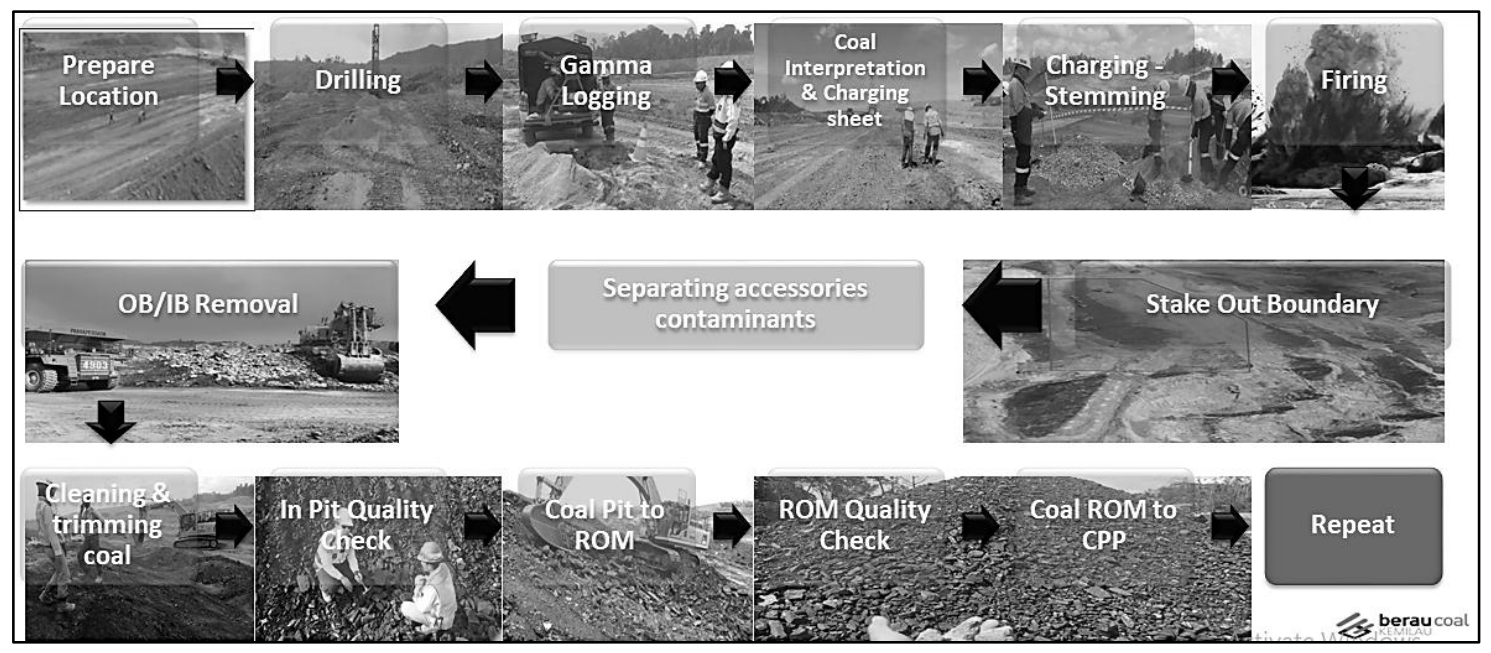

Gambar 6. Tahapan proses pra peledakan - peledakan - pasca peledakan

\section{C.2. Perencanaan, Proses, Hasil, dan Evaluasi}

Plan, dalam merencanakan trial implementasi metode through seam blast ini menggunakan konsep SMART (specific, measureable, achievable, realistic, timely). Konsep SMART sangat membantu dalam menyusun perencanaan yang efektif dan efisien. team TSB yang dibentuk berkumpul dan berkoordinasi dalam penyusunan perencanaan secara komprehensif dan sistematis. Dari hasil koordinasi dan proses brainstorming yang dilakukan ditentukanlah parameter keberhasilan dari trial implementasi metode through seam blast ini seperti pada gambar 7.

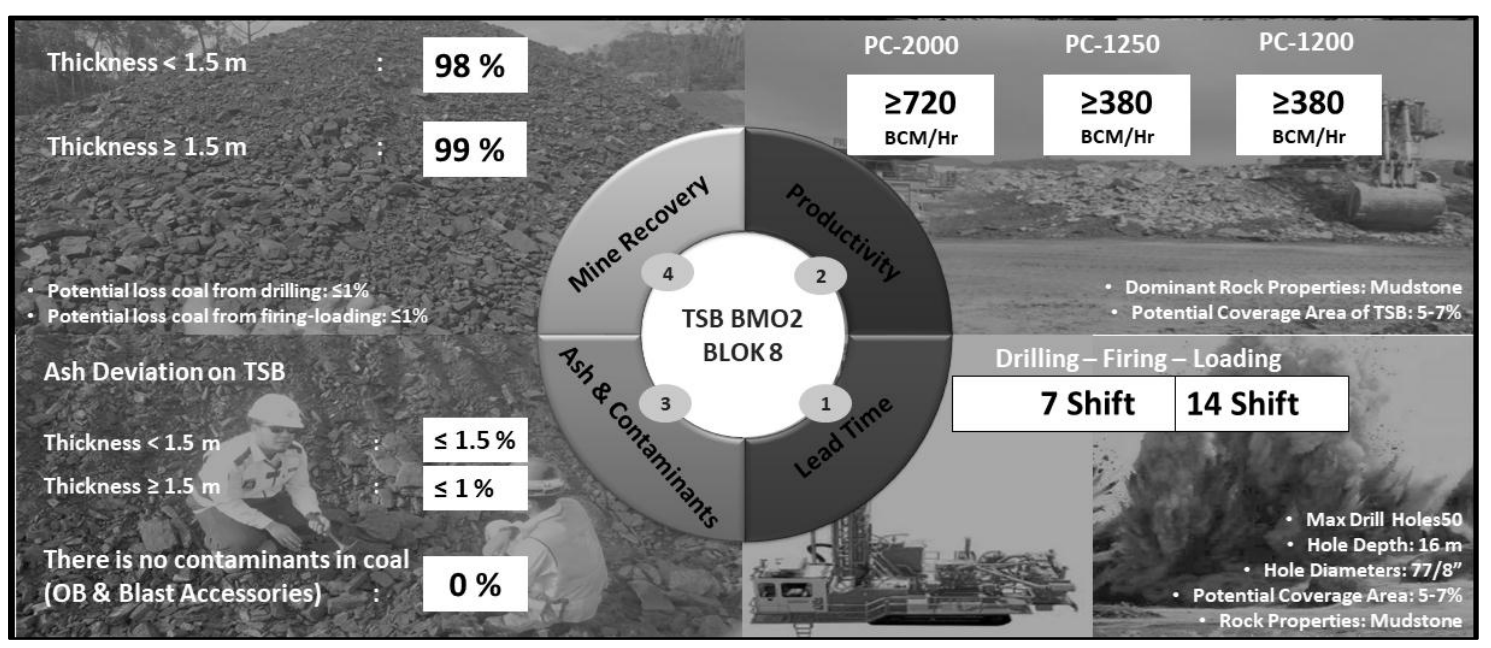

Gambar 7. Parameter keberhasilan trial implementasi metode through seam blast

Bagian hulu dari sebuah perencanaan adalah penentuan tujuan dan batasan yang tegas dan jelas dari setiap do dan action yang dilakukan sehingga tidak ada bias pada saat mentransformasi rencana menjadi tahap implementasi. Metode through seam blast diharapkan memberikan dampak positif dalam operasional secara menyeluruh, sehingga ditentukan empat parameter keberhasilan yaitu: 
- Lead time drilling - firing - loading

- Productivity

- Ash \& Contaminants

- Mine recovery

Keempat parameter ini menjadi fokus ukuran keberhasilan dari proses trial implementasi metode through seam blast di Pit C1 Blok 8 BMO 2 PT Berau Coal.

Do, setelah plan tersusun dan disepakati, team tsb kembali melakukan koordinasi dan pembagian tugas sesuai dengan tahapan yang sudah disepakati menjadi fokus penelitian.

- Sub-team drill and blast fokus mulai dari preparasi area sampai dengan firing sehingga proses dan dampak dari peledakan terkontrol dan sesuai baku mutu, sehingga memberikan hasil yang optimal baik dari segi kuantitas dan kualitas.

- Sub-team Produksi saling berkolaborasi mulai dari section OB removal, Coal mining and hauling, Pit Geologist untuk dapat fokus mengontrol performa produktivitas alat gali-muat dan kualitas penambangan batubara dimana dilakukan sampling batubara di tiga titik tahapan yaitu pasca cleaning (kualitas insitu), pasca trimming (kualitas stock inpit) dan ROM temporary (kualitas stock ROM).

Check and action, setelah setiap tahapan dalam satu proses trial implementasi metode through seam blast dilakukan dan setiap informasi terdokumentasikan, maka selanjutnya adalah proses analisis dan evaluasi. Adapun data hasil dari setiap proses yang diringkas kedalam empat parameter keberhasilan dapat dilihat pada gambar 8 .

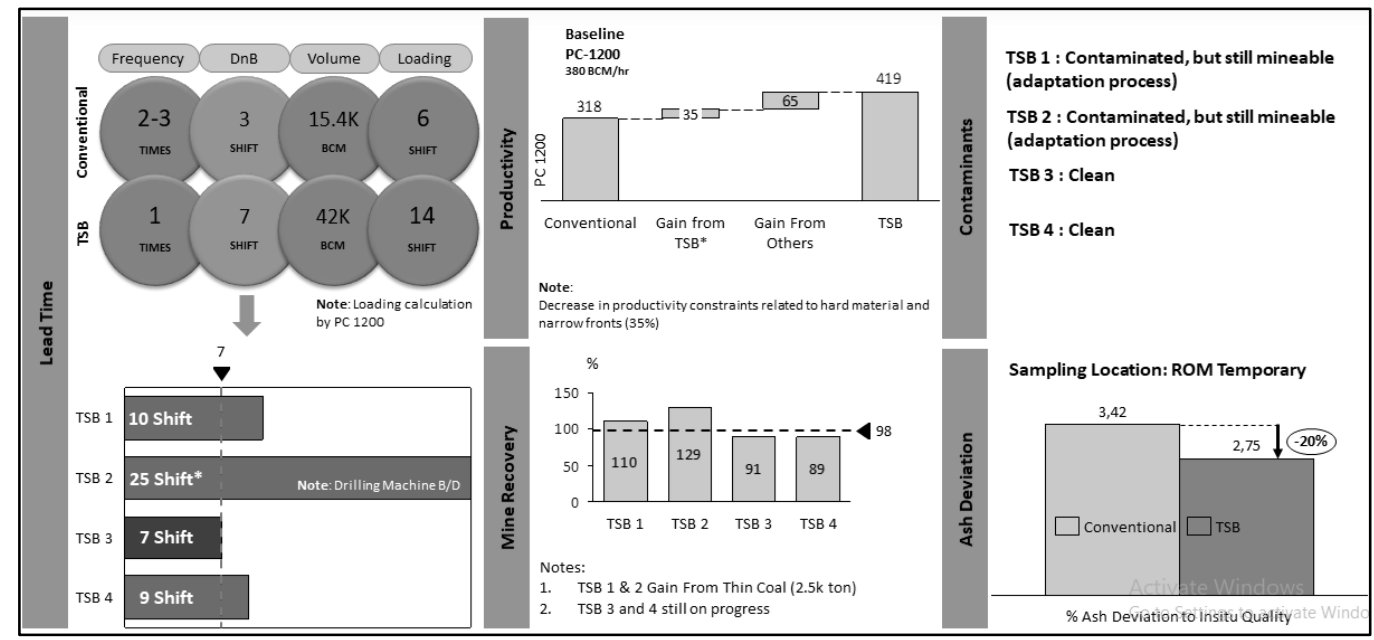

Gambar 8. Trial through seam blast outcomes (success parameters)

Lead time, untuk mendapat volume yang sama, frekuensi peledakan dapat dikurangi menjadi 20$30 \%$ dengan menggunakan metode through seam blast. Tidak hanya itu, metode ini dapat meningkatkan coverage area peledakan 20-30\% pada area yang sama dibandingkan dengan metode peledakan konvensional.

Berdasarkan data yang diperoleh dari empat kali trial, lead time perparasi area sampai dengan peledakan berhasil mencapai target tujuh shift pada trial yang ke-3. Trial 1,2,4 masih terdapat kendala yang relatif berbeda antar satu sama lain sehingga masih belum dapat mencapai target lead time yang diharapkan. Adapun yang menjadi perhatian selama proses persiapan area sampai dengan peledakan adalah pengawasan dan dokumentasi dari setiap tahapan untuk merekam semua data dan fakta. Dalam hal man power, Pengalaman operator pengeboran untuk menyediakan lubang sesuai dengan rencana dan tidak collapse. Dalam hal metode, Pengeboran dilakukan parallel dengan aktivitas gamma logging. Lalu, charging dan stemming dilakukan dengan charging 
sheet dan menggunakan stemtruck untuk meningkatkan efisiensi dan efektivitas stemming. Kemudian, penyediaan stick untuk kondisi wet and mud holes.

Productivity, seperti yang terlihat pada gambar 9 metode through seam blast dapat meningkatkan produktivtas alat gali-muat \pm 35 m $/ \mathrm{jam}(11 \%)$ untuk kelas EX-1200 Hitachi. Hal ini sejalan dengan peningkatan coverage area peledakan dalam satu lokasi peledakan, sehingga meminimalkan kendala material keras non-blasting. Digging time yang terecord berada pada interval $6.3-11.1$ detik dengan rata-rata 9.1 detik. Banyak parameter yang mempengaruhi produktivitas alat gali muat, sehingga untuk mendapatkan produktivitas alat gali muat yang optimal harus memperhatikan fakto-faktor yang mempengaruhi produktivitas, tidak hanya terbatas pada peningkatan kualitas material, tetapi juga pada skill operator, kondisi front kerja, match factor, dan lain-lain.

Mine recovery and coal quality, parameter hilir produksi yang ikut menjadi pertimbangan dalam menilai keberhasilan implementasi metode through seam blast. Upaya meningkatkan performa progress sekuen penambangan tidak berarti mengabaikan hasil dari penambangan batubara baik dari segi kuantitas maupun kualitas.

Berdasarkan data, mine recovery di area yang diimplementasikan metode through seam blast berada diatas target $\geq 98 \%$. Secara kualitas batubara yang tertambang di area yang diimplentasikan metode through seam blast secara bertahap menunjukan trend positif. Adapun yang menjadi perhatian dalam menjaga performa mine recovery and coal quality adalah pengawasan dan dokumentasi dari setiap tahapan untuk merekam semua data dan fakta. Dalam hal man power, Pengalaman operator coal cleaning dan coal getting menjadi salah satu kunci terhindarnya dilusi dan kontaminan dari batubara. Dalam hal metode, pemilihan geometri peledakan, charging, penentuan stand-off dan interpretasi data logging menjadi salah satu kunci terhadap kontrol tingkat ketergangguan batubara dari efek peledakan.

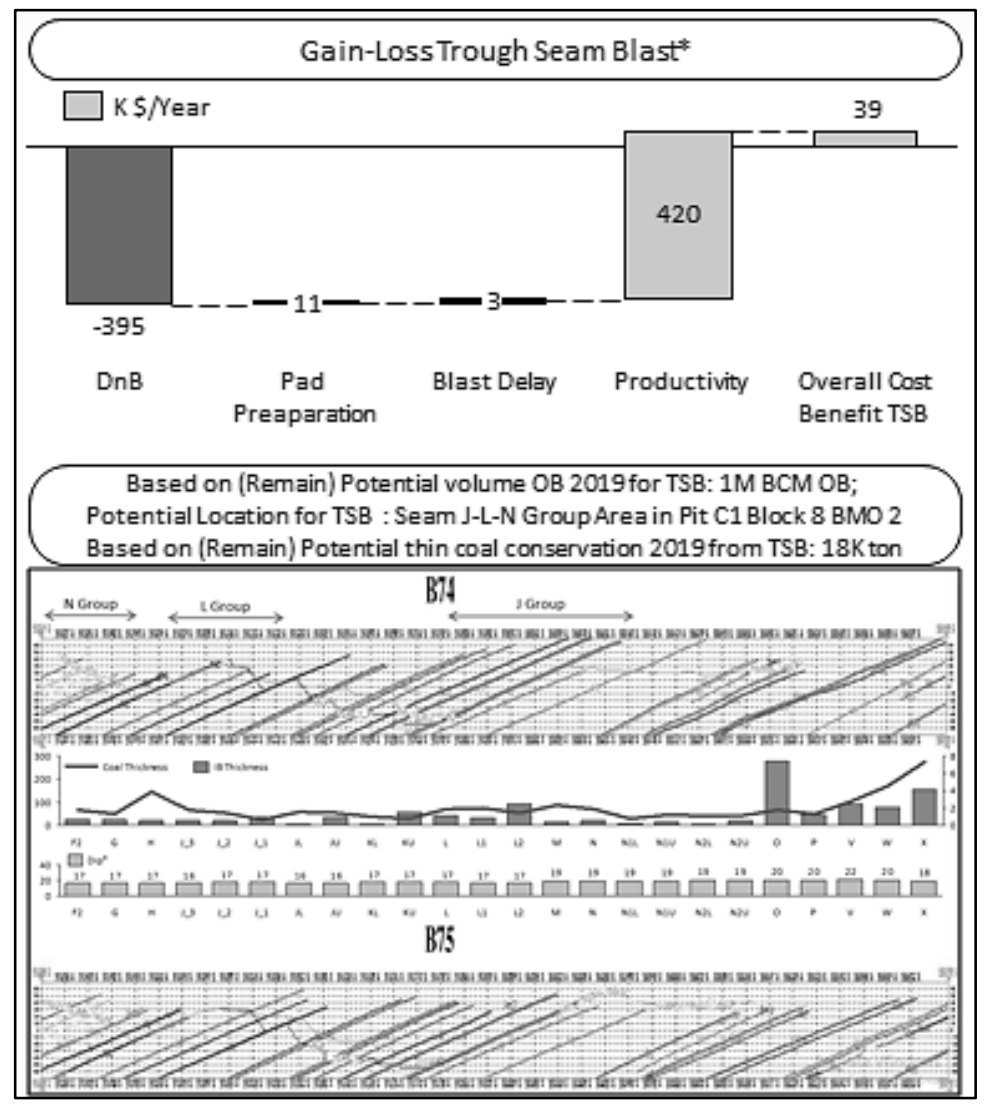

Gambar 9. Gain-loss metode through seam blast dan potensi optimasi thin coal 
Gambar 9 menunjukan cost benefit dari metode through seam blast dimana terlihat bahwa terjadi peningkatan biaya yang signifikan dalam tahapan pengeboran dan pengeboran. Namun demikian, dengan berkurangnya upaya persiapan lokasi dan frekuensi peledakan serta meningkatnya produktivitas terjadi cost efficiency dan secara keseluruhan metode through seam blast ini dapat memberikan cost efficiency sebesar 39.000 \$/tahun pada potential volume OB yang dapat diimplementasikan metode through seam blast sebesar $1.000 .000 \mathrm{~m}^{3}$.

Disamping itu, dengan terpangkasnya lead time proses pada metode through seam blast memungkinkan untuk dilakukannya optimasi konservasi batubara tipis di area yang diimplementasikan metode ini. Potensi batubara tipis tersebar pada lapisan batubara $N, L$, dan $J$ group sebesar 18.000 ton sampai akhir tahun 2019.

\section{KESIMPULAN}

Berdasarkan uji coba dan analisis yang sudah dilakukan, diperoleh kesimpulan bahwa:

1) Lead time persiapan area pengeboran sampai dengan peledakan memungkinkan berkurang sebesar 20-30\% dengan kontrol dan koordinasi yang komprehensif dan masif. Untuk mendapatkan volume yang sama, frekuensi blasting dapat diturunkan 1:3 dibanding metode peledakan konvensional. Dampak turunannya adalah menurunkan loss time karena aktivitas blasting.

2) Produktivitas alat gali muat meningkat $35 \mathrm{~m}^{3} / \mathrm{jam}$ (11\% pada kelas EX-1200 Hitachi). Hal ini sejalan dengan dengan peningkatan coverage area peledakan dalam satu lokasi peledakan, sehingga meminimalkan kendala material keras non-blasting. Digging time yang terecord berada pada interval $6.3-11.1$ detik dengan rata-rata 9.1 detik.

3) Mine recovery and coal quality menunjukan trend positif dan memungkinkan untuk terus ditingkatkan dan diperbaiki. Potential loss coal daari aktivitas pengeboran dan penambangan batubara masih dalam toleransi dan dapat dikompensasi dari peroleh konservasi batubara tipis, begitupula pada pemenuhan kualitas batubara yang terbebas dari dilusi dan kontaminasi. Data dan fakta yang diperoleh disetiap trial menjadi acuan dalam perbaikan yang berkelanjutan.

\section{UCAPAN TERIMA KASIH}

Team TSB mengucapkan terimakasih kepada manajemen PT Berau Coal yang telah memberikan ruang untuk melakukan perbaikan yang berkelanjutan. Tidak lupa ucapan terimakasih dan rasa bangga kepada segenap pihak baik PT Berau Coal maupun mitra kerja yang terlibat dalam keseluruhan proses trial implementasi metode through seam blast di Pit C1 Blok 8 Binungan Mine Operation Area 2 PT Berau Coal sehingga uji coba ini dapat terlaksanadengan baik. Evaluasi dan perbaikan akan terus dilakukan guna memberikan dampak positif terhadap operasional penambangan di PT Berau Coal.

\section{DAFTAR PUSTAKA}

Brilianto, A. (2010): Geologi Dan Identifikasi Seam Batubara Berdasarkan Data E-Log dan Sifat Fisik di Permukaan Blok Kelai PT Berau Coal, Universitas Pembangunan Nasional "Veteran", 78-90.

Situmorang R. L. dan Burhan, 1995, Peta Geologi Regional Lembar Tanjung Redeb, Kalimantan, Pusat Penelitian dan Pengembangan Geologi, Bandung. 
Sujit, K., Bhadra, M., Mukherjee, T. K., dan Himanshu, V. K. (2017): Extraction of contiguous seam and overburden using through seam blasting technique, NexGen Technologies for Mining and Fuel Industries, 195 - 200.

Gambaran umum mengenai Through Seam Blasting, diperoleh dari situs internet: https://www.dynonobel.com/ /media/Files/Dyno/ResourceHub/Case\%20Studies\%20and\%2 0Abstracts/Through\%20Seam\%20Blasting.pdf. Diunduh pada tanggal 7 September 2019.

Gambaran umum mengenai Through Seam Blasting, diperoleh dari situs internet: https://id.scribd.com/doc/50601321/Through-Seam-Blasting-bahasa. Diunduh pada tanggal 7 September 2019. 
PROSIDING TPT XXVIII PERHAPI 2019 